\title{
結晶化ガラス『ミラクロン』について
}

増 田 泰 朋*

（昭和 38 年 12 月 14 日受理）

\section{On "Miraclon"}

Yasutomo MASUDA

(Research Laboratory, NGK Insulator's Ltd., Mizuhoku, Nagoya. Japan)

\section{1. 『ミラクロン』とは}

科学技術の進歩発展に伴って、より優れた新しい材料 方要求され、その開発が促されることはよく知られると ころである。

純酸化物磁器、強磁性セラミックス、サーメット、強 誘電磁器、窒化物、嗍化物、炭化物などのいわゆるニュ 一セラミックスが戦後急速な進歩をとげ、各分野に寄与 乙ていることはすでに御承知の通りである。

これらニューセラミックスの分野でも、比較的新しく 開発され、注目されているものに結晶化ガラスがある。 この分野では、1957年米国コーニング社が「アルミニウ ムより軽く、鋼より強い材料」として、「パイロセラ ム」(Pyroceram)」なる商品名で発表したのがその始 めである。結晶化ガラス浪名グラスセラミックス、

(Glass Ceramics)、またはデビトロセラム (Devitroceram) とも呼ばれている。

『ミラクロン』は日本碍子K K Kで開発された結晶化ガ ラスの商品名であり、すでに生産を行っている材料であ る。

ミラクロンは特殊な核形成剤を含えだガラス原料を一 度溶融してガラスを造り、通常のガラス成形法と同㥞な 方法で所望の形状に成形し、これを特定の加熱処理によ って結晶化させて得られるもので、一ロにいえば、ガラ スからつくったセラミックスである（第1図）。以下こ れについて簡単にご紹介する。

\section{2. ミラクロンの製法}

ミラクロンの製法は、目的とする製品によって多少異 なるが、一般的には第 2 図に示す工程を経る。

所定の原料調合物を高温で完全溶融させ、均質なガラ

* 日本碍子株式会社研究所 (名古屋市瑞盉区堀田通り2の1)

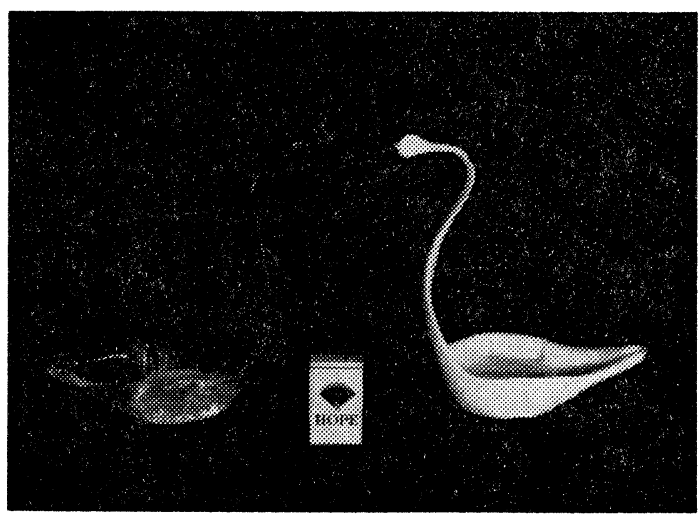

第1図 ガラスから結晶へ

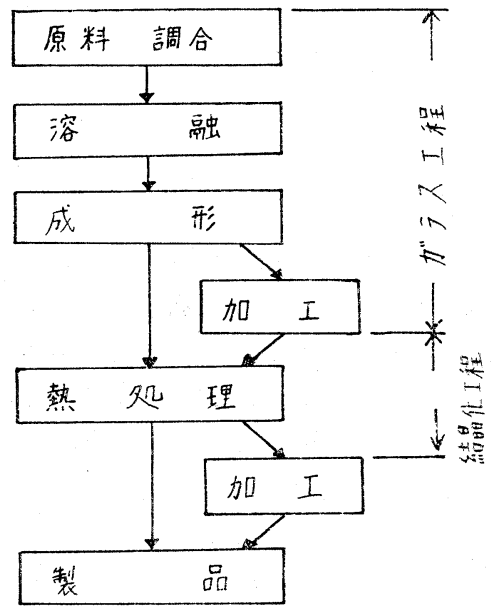

第 2 図 ミラクロンの製造工程

ス状としてから、目的とする形状に成形する。この際採 られる成形方法は、通常のガラス成形法之ほぼ同じであ り、したがって、棒、パイプの類、容器物、板状のもの、 ブロックその他のプレス品、ボールなどは、比較的容易 に得ることができる。ここに得られた成形体は、外観上 
は、普通のガラスとほとえど変りのないものである。

この成形体に、必要に応じて、切断、研磨、穴㐫けな ぞの機械加工を施したり、あるいは再び加熱軟化させ て、所定形状にするいわゆる熱加工を施したりするとと のできるのは、通常のガラスの場合と全く同じである。

つぎに、このガラス成形体に、結晶核発生・成長の理 論に基く特定な加熱処理を施す。この熱処理（結晶化） 過程で、ガラス中に極めて微細な結晶が均一に析出し、 全体が陶磁器質に変り、機械的強度、酎熱性、耐摩耗性 などの各特性が格段と向上した製品がえられる。

このあとさらに精密寸法を要するものについては、通 常の磁器と同様な機械加工を施すことができる。

以上のように、ミラクロンの製造工程は、ガラス工程 と結晶化工程の二工程に大別される。

上記製造工程をとることから考えると、ミラクロンに は次のような利点がある。

i）大量生産方式の採用が可能である。 ガラス状態で成形を行うため、大量生産方式を採る ことができ、その結果、需要の拡大と共にコストの 大巾な低下を期待しらる。

ii）特殊形状・寸法品の製作が可能となる。 成形後乾燥、焼成という工程をとる従来の陶磁器製 造法では造りえない特殊形状寸法のものが製作可能 となる。とくに従来の陶磁器では、焼成による収 縮は10\%以上であるため、寸法精度の高いもの、薄 肉のもの、西るいは厚肉のもの、形状の複雑なもの などは製作困難であったが、ミラクロンの場合、成 形体浰処理後もほとんぞ寸法変化がないため （収縮率 $1 \%$ 以下）、与えた形状、寸法のまま最終 製品が得られる利点がある。

iii）品質の完全保証。

ガラス工程によってできた成形体は、透明であるた め、気泡、脈理などの内部欠陷や内部歪、表面の傷な どを容易に検出できる。このため、無欠陷製品の選別 が容易となり、高度の品質保証が期待できる。また 一度完全均一に溶融したガラスを成形して製品とす るために、部分的な材質の不均質性がみられない。

iv）製作日数を短縮することができる。

従来の陶磁器に比べ、製作日数を著しく短縮しらる

\section{3. ミラクロンの特性}

現在実用化されているものについての各特性は、第 1 表に示した通りであるが、ミラクロンにはガラスと磁器 の長所をかね称をなた面白い特質がタられる。

原料、組成を適当に変えることによって、各特性值も
第1表ミラクロロンの特性

\begin{tabular}{|c|c|c|c|c|}
\hline 特 性 & 単 位 & $\mathbf{A}$ & B & $\mathrm{S}$ \\
\hline 比重 & & 2.45 & 2.42 & 2.98 \\
\hline 吸 水 率 & $\%$ & 0 & 0 & 0 \\
\hline \multirow{2}{*}{$\begin{array}{c}\text { 熱膨脹係数 } \\
\left(/{ }^{\circ} \mathrm{C}\right)\end{array}$} & $\begin{array}{r}100 \sim \\
300^{\circ} \mathrm{C}\end{array}$ & $75 \times 10^{-7}$ & $51 \times 10^{-7}$ & $5 \times 10^{-7}$ \\
\hline & $25 \sim 800^{\circ} \mathrm{C}$ & $91 \times 10^{-7}$ & $66 \times 10^{-7}$ & $10 \times 10^{-7}$ \\
\hline 軟 化 点 & ${ }^{\circ} \mathrm{C}$ & 920 & 920 & 1250 \\
\hline 熱伝導率 & \begin{tabular}{c|}
$\mathrm{cal} / \mathrm{sec} /$ \\
$\mathrm{cm}^{2} / \mathrm{cm} /{ }^{\circ} \mathrm{C}$
\end{tabular} & 0.003 & 0.003 & 0.003 \\
\hline 冷熱温度差| & ${ }^{\circ} \mathrm{C}$ & 100 & 200 & 750 \\
\hline 曲げ強 度| & $\mathrm{kg} / \mathrm{cm}^{2}$ & 2000 & 1450 & 1300 \\
\hline 引張強度 & $"$ & 800 & 580 & - \\
\hline 圧縮 強 度 & " & 5000 & 3500 & - \\
\hline ヤング率 & " & $9.5 \times 10^{5}$ & - & - \\
\hline $\begin{array}{l}\text { 硬度 }^{(ヌ ー-~} \\
\left.\mathrm{J}^{\circ} 100 \mathrm{~g}\right)\end{array}$ & $\mathrm{kg} / \mathrm{mm}^{2}$ & 860 & 600 & 550 \\
\hline $\begin{array}{l}\text { 体積固有抵 } \\
\text { 抗 }\end{array}$ & $\begin{array}{c}\Omega-\mathrm{cm} \\
\left(25^{\circ} \mathrm{C}\right)\end{array}$ & $6 \times 10^{14}$ & $6 \times 10^{13}$ & $6 \times 10^{12}$ \\
\hline 誘 電 率 & $\begin{array}{l}10 \mathrm{KC} \\
\left(25^{\circ} \mathrm{C}\right)\end{array}$ & 6.8 & 10.3 & $\left(\begin{array}{c}9.6 \\
(1 \mathrm{KC})\end{array}\right.$ \\
\hline \multirow{3}{*}{$\tan \delta$} & $\left.1 \mathrm{~N} \mathrm{c}^{\prime} 25^{\circ} \mathrm{C}\right)$ & 6.8 & 10.2 & 8.6 \\
\hline & $10 \mathrm{Mc}(")$ & 0.006 & 0.010 & $\begin{array}{c}0.05 \\
(1 \mathrm{KC})\end{array}$ \\
\hline & $1 \mathrm{Mc}(")$ & 0.004 & 0.003 & 0.02 \\
\hline 絶 縁 耐力 & $\mathrm{kV} / \mathrm{mm}$ & 13 & 13 & - \\
\hline $\begin{array}{l}\text { 酎酸度(JIS } \\
\text { 粉末法) }\end{array}$ & $\mathrm{mg} / \mathrm{cm}^{2}$ & 0.18 & 0.61 & 0.90 \\
\hline
\end{tabular}

変化するが、一般的な特徴を列記すると次の通りであ る。

i）機械的強度が大きい

普通のガラス、磁器の $3 \sim 4$ 倍のものもえられる。 表面の硬度、耐摩耗性もガラスより大きいこと沕 論、普通磁器よりも優れている。これらの特質は機器 の小型化へ大きく寄与するものといえる。

ii）熱膨脹を任意に選べる。

石英ガラスとほとえど同じょうな低膨脹のものか ら、軟鋼のような膨脹の高いもの㚓範囲にわたっ て、要求する熱膨脹の組成を、相当自由に選ぶことが できる。このことは、他の材質との複合製品をえる場 合有利となる。

また低膨脹組成のものは、熱衝撃に強く、かかる分 野への応用が期待できる。

ili） 耐熱性がガラスより大きい。

ガラスは普通 $500^{\circ} \mathrm{C}$ 程度で軟化し、これ以上の温度 


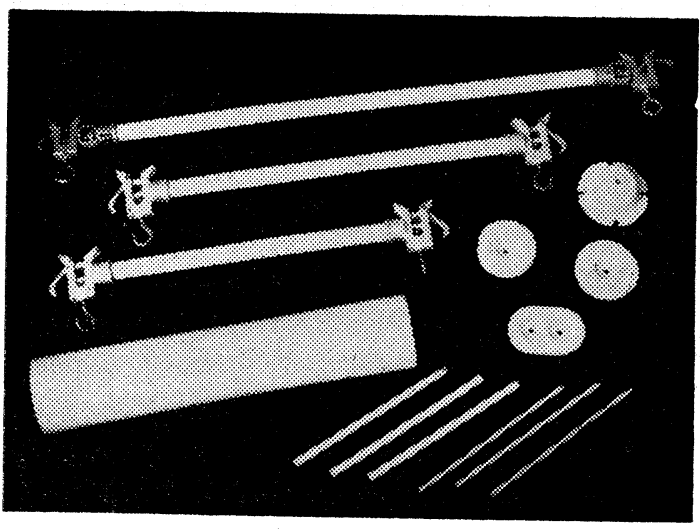

第3図 電気絶緣帆料と乙ての応用例

(ラインスベーサー、小型碍子、絶縁ロッド)

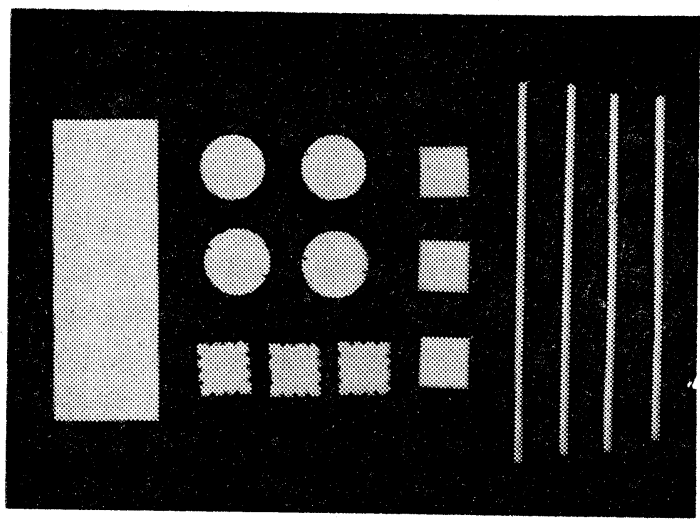

第 4 図 電子工業分野への応用例

(M.M.W. 蒸着基板、抵抗基体など)

下での使用に耐えないが、ミラクロンの軟化温度は、 900〜 $1200^{\circ} \mathrm{C}$ であため、高温で使う分野ではガラス にまさる。また石英ガラスのように失透を生じない。 iv）表面が平滑である。

表面の平滑度はガラスに近いので、結晶化したまま の面でも、磁器の研磨面以上の平滑度がえられる。し たがって普通磁器のように釉薬安かける必要もない。

結晶の大きさが極めて 微細 ( $1 \mu$ 以下) であるため 鏡面庄えることもできる。

v）着色、絵付ができる。

素地の色（普通は乳白色）をピンク、黄、青などに 比較的自由に着色できる。また転写装飾もできる。

vi）赤外線を透し易い。

赤外線透過率は透明石英ガラスに比しやや低いが、 磁器よりははるかて高い。

\section{4. ミラクロンの応用分野}

ミラクロンがぞのような分野に、どの特質が生かされ て応用されているか、すでに開発されているものを例に

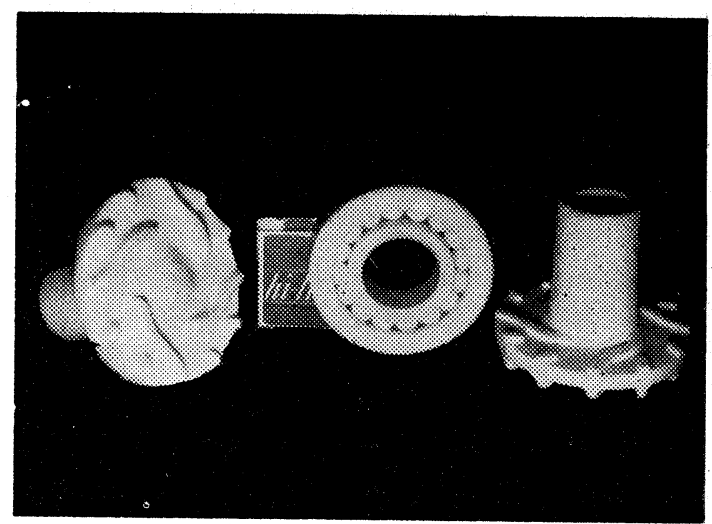

第 5 図 ポンプインペラー、ボールベアリングへの 応用例

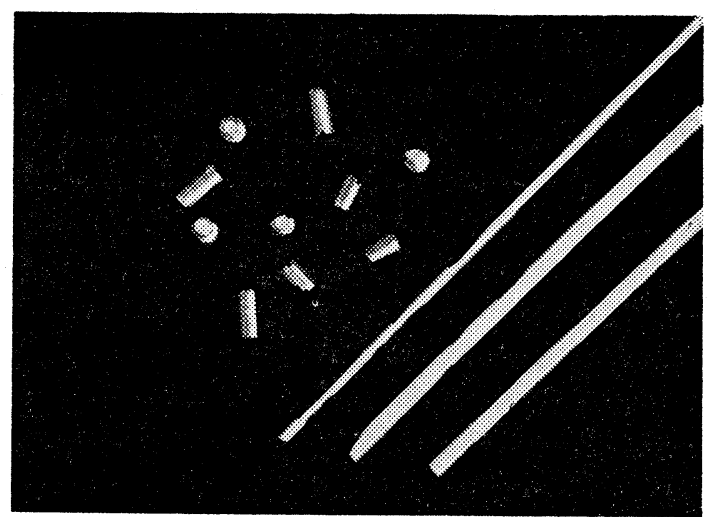

第 6 図計器用軸受への応用例

して簡単に紹介する。

（1）電気絶縁材料に（第 3 図）、

あらゆる電気機械器具の絶縁部材、および送配電用 の碍子、絶縁器具として使用される。例えば、ライン スペーサー、フューズ筒、小型碍子類、端子台、など である。

これらは何れも高強度、電気絶縁性がよい、表面平 滑で洗浄し易い、などの特質在生かした応用例であ る。この分野では成形技術の向上によっては、䀣垂碍 子、碍管などの大型製品も期待できる。

（2）電子工業材料に（第 4 図）、

ウェハー、パイプ、ロッド、あるいはマイクロモジ ニールウェハーの形状をとって、いろいろな回路素子 のベースとなるもの、あるいは単なる絶縁体として使 われる板、パイプ、ロッドがある。前に述べたよう に、ミラクロンは従来この分野に使われている磁器で はほとえど不可能とされていた鏡面がえられるので、 蒸着によって素子を造る場合泩他材に比し安定した性 能のものを得ることができる。またガラスやマイカな 


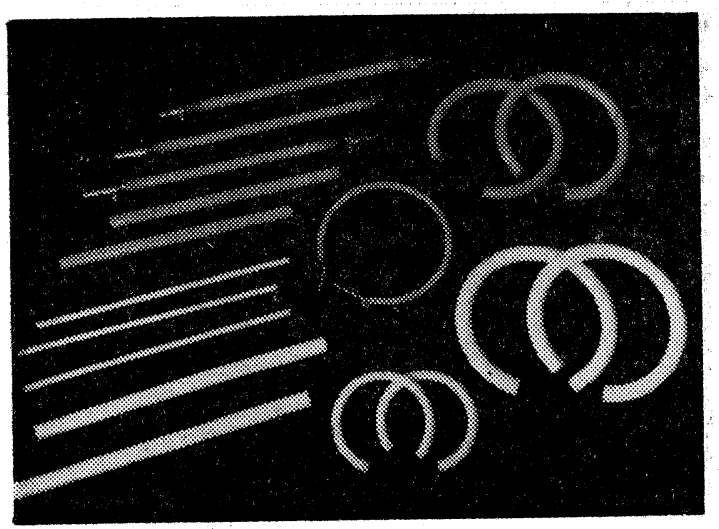

第 7 図 熱器具への応用例 (赤外線ランプ、ヒー ター外囲管など)

どに比べても、強度や最高使用温度が高いので、素子 の使用限界を拡げることができる。

（3）機械材料に（第 5 図）、

化学工業用としてポンプインペラー、ポンプケーシ ング、シャフト、ボールバルブ、ベアリング、ボル ト、搬送用パイプ、タンクなどの一連の樂統装置の部 品や、糸道、紡糸用ノズルなどがある。これらは何れ もミラクロンの成形性のよさ、耐蝕性。耐摩耗性の よさ、高強度を生かして応用されているものである。

（4）精密機器部品に、

時計、電気計器、各種工業用計器、カメラ露出計な ぞの精密機器は、高い精度とより長い耐久性を要求さ れるが、その心臟部ともいえる振り子、あるい恉針 の゙軸受”にミラクロンが使われている。これはその 加工性、酎摩泣性の良さ、高強度が生かされた応用例 であるが、従来使用されているメノウ、サファイア、 ルビーなどとその性能を比較すると、ミラクロンは耐 摩耗性も優れ、軸材との摩擦係数も小さく、また加工 性も良いことがわかり、優秀な軸受材料として認めら れている(第6図)。

この他に、“時計用瓜石・振石”、計器指針ストッパ 一、天科用ナイフェッジ、ピボットなどに応用され、 またその弾性を利用して板バネ、フラッパーなどに応 用することも可能である。

(5) 酎熱材料として（第７図）、

ストーブ、コタッ、ロースターなどの家庭用電熱器 具に、その発熱体 (Ni-Cr線などの) の外囲材として 使用される。ミラクロンの赤外線透過度は、石英より やや低いが、従来の陶磁器に比べるとはるかに高い。 したがって陶磁器製の外国材を使った熱器具に比べる と、伝熱効率が良く、また石英のような失透脆化現象 が起らない。さらに高強度のために、使用中の破損の

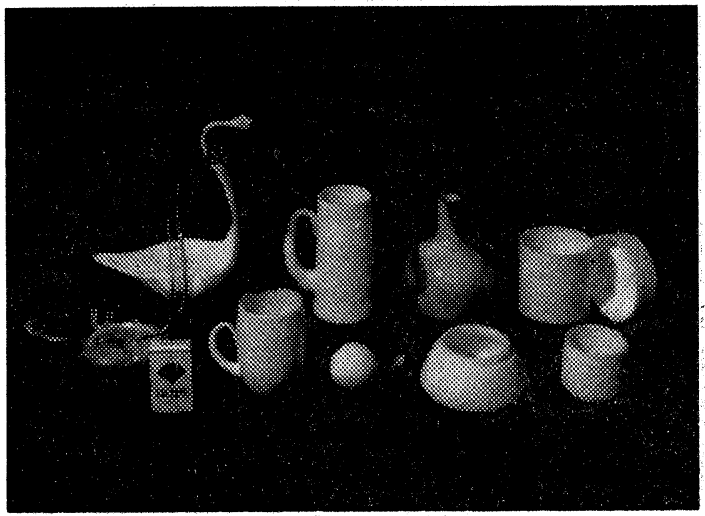

第 8 図各種 容器類

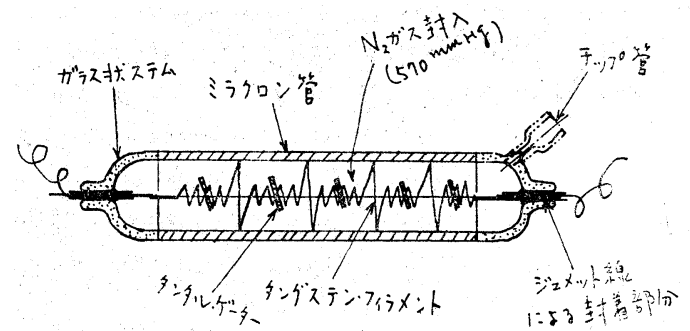

第 9 図 ミラクロン・ランプの基本的構造

心配がなく安全である。また複雑な形状例えばU字 管、環状管、螺旋状管などの加工もできるので、外観 上からも、性能上からも、目的によっていろいろな形 状の発熱体をうることができる。

$\mathrm{Ni}-\mathrm{Cr}$ 線の代りに発熱体としてタングステン線を内 部に入れ、不活性ガスを封じ込えで"ランプヒーター゙ とすることも可能であり、上記電熱器具の発熱体とし て使用される。

この他に、メッキ液の温度調節用 投込ヒーターの 外囲管 や、石油ストーブの ホヤなどがある。また 比較的低温下であるが、炉心管、保護管、セッターな どにも使用される。

以上のように、高強度耐熱材料としてのミラクロン の用途は広く、とくに低膨脹ミラクロンは、石英ガラ ス、硼珪酸ガラス、アルミナ質磁器に代わる材料とし て期待される。

（6）日用品として（第 8 図）、

コップ、血などの台所用品、その他容器類は、その 高強度と外観美麗で格調の高いところを称らった忘用 例である。容器として特殊なものに、魔法瓶、ジャ一 がある。従来のガラス製魔法瓶の宿命的な欠点である 自爆 (成形加工時の残留応力による自然破壊のこと) は、ミラクロン製にすることによって、完全に無くす ることができた。 
低膨脹ミラクロンは、耐熱食器として使われる。 (7) その他

外装建材、ボールペン用ボール、自記記録計用ペン 先、半導体加工用の治具、プラスチックス成形用型、 注射器などにも応用される。これらは上述のミラクロ ンの持つ特質を充分に生かした適用例である。また特 殊な用途として印鑑材がある。これはミラクロンの彫 刻性、耐摩耗性およびその持つ格調から、水晶や水牛 の角に代わる材料として提供されている。さらに着色 されたミラクロンは、装飾品の分野にまで入り、色ガ ラス、人造宝石と刑えでその価值圭発揮するもの。

(8) 真空技術の分野に

前に紹介した赤外線ランプ、魔法瓶は、この分野に 関係した応用例である。

ランプヒーターの原理的な構造を（第 9 図）に示し た。ステム部 (リード線導出部) の封着方法は基本的 には一般ガラス管球の場合と同様であるが、素材の一 部老部分的に結晶化できる、結晶とガラスの接着が可 能である、などのミラクロンの特質を利用して加工さ れる。300W (100V) の試作ランプについて、通電試 験安行ったが、連続通電約 $3000 \mathrm{Hrs}$ 、on-off 通電約 20,000 Cycle後む、性能的に通電初期の状態とほとん ど差がないという結果をえている。

魔法瓶の二重壁間の真空度は、10-4 $\mathrm{mmHg}$ まで要求 されるが、最終工程であるチップ管の溶封は、通常のガ ラス製魔法瓶におけると同椂な方法が採られ、溶封時 にガラス化した部分は、再び熱処理するか、あるいは
そのままの状態にあっても、真空度の劣化のないこと を確認している。

以上㶕単な例であるが、この他にも電子管、放電 管、電球、ブラウン管などの管球用材料として応用す るととも可能であろう。

真空部品にミラクロンを利用すると

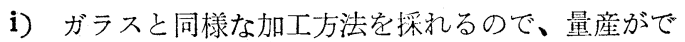
きる。

ii） ベーキング温度を高くすることができるので、 各部材よりの脱ガスが完全に行なわれ、したがって 製品の寿命を長くすることができる。

iii）強度が高い。

の点で有利となる。

以上のように、ミラクロンの用途多多面に亘ってい るが、さらに品質や生産技術の向上によって、今後一層 広範囲な用途の開発が期待できるものである。

\section{5. 結 び}

日本碍子に打いて開発された新材料、結晶化ガラス 「ミラクロン」について、主としてその製造方法、特性、 応用例飞ついて概略説明し、最後に真空部品への応用例 について簡単に紹介した。御参考の一助ともなれば幸で ある。

ミラクロンは開発されてまだ日も浅く、材料品質や成 形加工支術に不充分な点を残しているが、今後の研究に よってこ机らを解決し、各種工業の発展のために貢献で きるものと期待している。

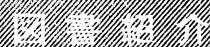

A. Guthrie 著 John Wiley and Sons 社、

\section{Vacuum Technology}

1963年、532頁、4500円
A. Guthrie $は$ "Vacuum Equipment and Techniques (McGraw-Hill社、1949年) の著者、1957〜1958 年の米国真空協会の会長、現在、カリフォルニア州立大 学の物理学教授である。

この本は前の本と異なり、真空技術の研究者を対象に したものではなく、現場の技術者のために書かれた初歩 的、実際的な解説書である。どんな分野に属する人にも 読めるよらに、真空技術に関する極く基楚の物理垷象か ら説明してある。真空装置を購入し、これの据つけ、運 転、保守を仕事とするような人が机の上に置いて、日頃 開いて夕るのに適している。そのため算術以外は全く使 わないという方針で、計算図表やチャートを豊富に入れ てあり、指数や対数までも説明している。英語も非常に 平易簡明である。

内容はつぎの通りである。1. 真空の基璴的概念、2 真
空装置の一般的な説明、3. 回転ポンプ、4. 蒸気噴射ポン プ、5.その他のポンプ、6. 圧力測定 (真空計のこと)

7. 排気速度の測定法 8. 真空井材料の性質、装置をきれ いにする技術、10. 装置の組立て技術(シール、溶接、ろ う付け、ガスケットなど)、11. バッフル・トラップ・ バルブ、12. 真空用部品、13. 普通の真空装置、14. 超 高真空装置、15. リーク探しと修理。各章には、最近の新 しい涪題もとり入れてある。特て排気速度の測定法、装 置をきれいにする技術、装置の組立て技術の 3 章を設け てあるのはこの本の特色である。文りーク探しの力法や そのとめ力についても、相当の賁数をさいており、いろ いろ教えられることがでている。

このような、現場技術者向けの立派な本がたびたび出 版されるということは、それだけ真空工業が飛躍してき ていること意味するわけで、驚きに值する。（橋本） 